\title{
Arguments for austerity, old and new: the British Treasury in the 1920s and the Bundesfinanzministerium in the 2010s
}

\author{
Fernando J. Cardim de Carvalho* \\ Senior Research Scholar, Levy Economics Institute of Bard College, Annandale-on-Hudson, NY, USA and \\ Emeritus Professor, Federal University of Rio de Janeiro, Brazil
}

\begin{abstract}
Much of the criticism directed at austerity programs implemented after the 2007/2008 financial crisis, more forcefully in the eurozone, have relied on the same arguments Keynes and others raised against the (British) Treasury View developed in the 1920s and 1930s. Austerity, however, has been proposed most insistently in the 2010s by European authorities, led by the German Federal Ministry of Finance, the Bundesfinanzministerium (BMF). While the arguments for austerity then and now share some common elements, there are enough original arguments being presented by the BMF to make many of the criticisms ineffective. The paper reconstructs both views, the Treasury's and the $B M F$ ', to show and evaluate their similarities and their differences.
\end{abstract}

Keywords: fiscal policy, austerity, business cycles

JEL codes: E32, E62, E63

\section{INTRODUCTION}

When the sub-prime distress erupted in the United States, in the first semester of 2007, most analysts believed that it would be contained before it became a full-fledged financial crisis, let alone, even more certainly, before it turned into a deep recession. The reason for the widespread optimism was that economists and policy-makers were supposed to have learned the 'lessons' of 1930s. 'It,' as Hyman Minsky used to refer to the Great Depression, would not happen again because now policy-makers knew how to prevent it. Sub-prime mortgages were a relatively small segment of a large financial market. A financial crisis would require contagion to other segments, particularly to banks. This was, however, judged unlikely given the healthy capital coefficients all the large banks exhibited in the

\footnotetext{
* The author thanks the efforts of the two anonymous referees that really 'went the extra mile' in discussing and making suggestions to improve the original paper substantially. He is also grateful to EJEEP's editor, Prof. Dr Torsten Niechoj, for his comments and discussions. The paper was written when I was still the beneficiary of a research grant from the Brazilian National Research Council, CNPq, which has supported my work for most of my professional life. It has also benefited from discussions in seminars presented at the Institute of Economics, of UFRJ, Brazil, and in a Summer School at ISEG, University of Lisbon, Portugal. Of course, all remaining errors are my own responsibility.
}

Received 10 March 2016, accepted 14 July 2017 
United States at the time. ${ }^{1}$ Without contagion to the banking sector, the financial distress would remain local, devoid of meaningful systemic repercussions. In the worst case, governments in the affected countries were expected to rapidly adopt expansionary fiscal and monetary policies to prevent the operation of distress-amplification mechanisms, such as debt deflations and income multipliers. This was intended to stop any significant contractionary impulse in its tracks.

History, however, did not unfold in the way it was expected to. The securities markets crisis was in effect contained, but not before causing significant damage. Contagion did affect the whole financial system, not only in the United States but also in other countries, particularly in Western Europe. The near-collapse of financial systems paralysed credit and capital markets causing output and employment to fall. Rising liquidity preference led banks to hold increasing amounts of idle reserves as monetary authorities moved to increase market liquidity, and firms to pile up cash. Interest rates rose for practically everyone except the safest and most liquid borrowers, such as, notably, the US Treasury.

By late 2008 (and particularly after the Lehman Brothers episode), it was clear that the crisis had in fact become much more threatening than initially expected. It did affect productive activity and it was spreading worldwide. An extraordinary meeting of the G20's political leaders ${ }^{2}$ was called for November 2008 to coordinate a common global anti-crisis initiative. The participants of the meeting agreed that aggregate demand had to be supported by active demand management policies. In early 2009 , the newly inaugurated Obama administration followed up the recommendations with an almost US\$1-trillionworth fiscal package consisting of new spending and tax reductions. Some measures were also taken in the same direction in Western Europe, including Germany. It seemed that, in sharp contrast to the 1930s, coordinated expansionary policies would prevail over beggar-thy-neighbor measures. Global aggregate demand would be sustained and the world economy would sail out of the crisis scared but relatively unscathed.

These expectations were soon to be falsified. In the United States, the possibility of passing new programs of government spending was quickly buried by the remarkable hesitation of the Obama administration. After the Democrats' loss of majority in Congress in 2010, activist fiscal policy became all but impossible.

Developments in Europe were even more surprising. A few large banks, particularly in the United Kingdom, Switzerland, and Germany, were affected directly by the sub-prime crisis, still in its early stages. But the worst was to come, after the failure of Lehman Brothers. Some countries, such as Ireland and to some extent Spain, suffered contagion through their banking systems. Others, such as Portugal, were exposed to financial instability through their need for balance-of-payments financing. Still others had to finance fiscal budget deficits through the placement of bonds in international markets. Whatever the channels for contagion may have been, by 2010 some European countries were also facing serious crises, while others, such as France or Italy, were judged to be in a fragile condition, all of them hit by the deterioration in world financial markets. Paradoxically, this was also the time when some countries, led by Germany, broke the apparent 'Keynesian consensus' established in 2008. ${ }^{3}$

1. These were the times of Basel II, when a bank was considered safe by regulators when its capital as a proportion of assets weighted by their risk, estimated by banks themselves, reached a certain level. After the crisis, regulators finally found out that in-house risk calculations were deeply flawed, to say the least. This issue is examined in detail in Cardim de Carvalho (2015a).

2. The G20 comprises the ten largest advanced and the ten largest emerging economies.

3. It may or may not be a coincidence that the break in the Keynesian consensus was made explicit in the G20 2010 Toronto summit, when the financial crisis was beginning to hit the periphery of the eurozone. 
Concern about output and employment was replaced by concern about the size of fiscal deficits and public debt. The language of the G20 communiqués became ambiguous, trying to balance the demands of the two groups of country leaders, those pressing for reflation and adoption of expansionary policies, and those pressing for immediate fiscal consolidation and public debt reduction, in a word austerity.

Austerity is not the same thing as fiscal discipline, that is, the attempt to maintain close control over government spending and tax revenues, even as budget deficits eventually arise. Nor it is synonymous with balanced budgets or even budget surpluses, because these can be reached when economies grow at their full potential without any particular sacrifice. Fiscal austerity is the effort to balance the budget and reduce public debt under recessionary or depression conditions. ${ }^{4}$ Such an effort takes the form of spending cuts, a tax raise, or a combination of both. Since either spending cuts or tax raises reduce private-sector incomes, fiscal austerity can only increase output and employment from their recession levels if it leads private agents to decide to spend a larger share of their reduced incomes. Why would they do such a thing? The answer usually given by austerity-ers is that balanced budgets (or efforts to that effect by the government) increase investors' and consumers' confidence, inducing them to spend more instead of less. If it is the confidence of financial institutions that rises, they could increase their loans and support more private spending. The definition of fiscal austerity just presented will be the one adopted in this paper. It may or may not be accompanied by monetary tightening or attempts to liberalize labor markets. In the paper we will mention when such measures are also included in the austerity package, but they will not be examined for their own merits and demerits. ${ }^{5}$

The opposition between expansionists and austerity-ers was not confined to debates within the G20. As peripheral eurozone countries saw their financial position deteriorate dramatically and demanded the EU's support, austerity was enshrined in the rescue packages designed by what became popularly known as the troika (a tri-partite group formed by representatives of the European Commission, the European Central Bank, and the International Monetary Fund (IMF)).

At times, the confrontation between pro-expansion and pro-austerity partisans seemed to have been transplanted directly from the 1920s and 1930s dispute between 'expansionists' (today generally referred as 'Keynesians') and the 'Treasury View' espoused by the British government. The apparently strong return of the Treasury View in the 2000s took most people in the Anglo-Saxon countries by surprise. It was well known, of course, that orthodox economic theory had moved decisively towards the restoration of the prestige of Say's law among American academic economists since the 1960s. Few people believed, though, that policy-makers would actually propose austerity policies inspired by it. Continental Europe, on the other hand, seemed to offer a more complex picture. The Keynesian consensus that was shared after World War II until the late 1970s even by conservative governments in the United States and the United Kingdom was never as strong in continental Europe. The rise of social-democrat

4. Austerity-ers also see the year as the relevant time period in which budgets have to be balanced. A more flexible approach would result from considering longer periods of time (such as, for instance, the duration of the business cycle).

5. The recent literature on the virtues and defects of austerity is, as one would expect, large. To mention two other works published in this journal dealing with similar issues, we should point to Truger (2013) and Blyth (2016). The present paper largely shares Truger's views as to the effects of austerity, although it does not dwell on the results of policy focusing. Blyth (2016), following his influential book (Blyth 2015), emphasizes redistributive aspects of austerity policies from a political point of view, which are not explored in this paper either. 
and socialist parties in many Western European countries pushed governments toward a more active participation in the economy, but it rarely took the form of demand management beyond the adoption of automatic stabilizers. ${ }^{6}$ The conservative groups that controlled most of the governments in the region, for various reasons, maintained their aversion to Keynesian demand policies.

Be that as it may, the driving force of austerity in the 2010s is not held by the British Treasury but by the German Bundesfinanzministerium (hereafter the BMF). The central proposition of this paper is that to direct at the BMF the same criticisms leveled against the Treasury View is a mistake. 'Modern' views of austerity only partially reproduce the arguments of the 'old' Treasury View. To show how close (and how different) the two austerity views (espoused by the British Treasury and the BMF) are, in Section 2 we present the points raised by Treasury officials themselves, rather than their academic critics, against expansionist fiscal proposals in the 1920s and the 1930s. Section 3 tries to do the same with the arguments raised by modern proponents of austerity. This time, however, the main source was no longer the British Treasury, but the Federal Ministry of Finance and other entities of, or connected to, the German Federal Republic. An evaluation of both sets of arguments is offered in Section 4. Section 5 asks whether austerity works after all and how success is defined by austerity-ers. Section 6 concludes.

\section{THE TREASURY VIEW}

Middleton (1985: 180), echoing a point made by Robert Skidelsky, noted that economists, especially academic economists, tend to forget that the 1920s and 1930s debate around the Treasury View was not centered in universities or research centers. Rather, it involved civil servants, politicians, and some economists. Theoretical arguments most of the time took a back seat to operational and ethical concerns about the limits to legitimate government action. The Treasury View was frequently the object of caricatures because it was a difficult task to accurately portray its arguments. Civil servants in government seldom cared to produce doctrinal material of the kind one expects to examine in academic debates. Moreover, officials in function are not usually free to engage in public debates as academic economists are. Most of what Treasury officials had to say was manifested in internal documents not meant to be seen by outsiders. Only recently a representative collection of documents prepared by Treasury officials from 1925 to 1946, edited by G.C. Peden, was published (Peden 2004). It is a major contribution to the knowledge of how the Treasury View was structured and how it developed in time. The collection finally made it possible for researchers who do not have physical access to British government archives to know first hand what the Treasury View actually was after all.

As just observed, the Treasury View was never articulated as a full-fledged school of thought on policy choices, let alone macroeconomics. There is no founding document or text where its principles are listed, articulated into a consistent whole, explained and justified. It was expressed mainly through memoranda prepared by Treasury officials to answer demands from higher authorities (most frequently the Chancellor of the Exchequer), presentations as expert witnesses in Royal Commissions or, less frequently, to directly counter proposals presented by people outside government in newspaper articles, speeches, open letters, and manifestos. The closest one can get to a formal definition of the

6. Hall (1989) contains an excellent compilation of European experiences showing the limited diffusion of Keynesian principles of macroeconomic policy. 
Treasury View was offered by Winston Churchill, in a 1929 intervention in his budget speech at the House of Commons. ${ }^{7}$ Churchill stated that:

The orthodox Treasury View ... is that when the government borrow $[s]$ in the money market it becomes a new competitor with industry and engrosses to itself resources which would otherwise have been employed by private enterprise, and in the process raises the rent of money to all who have need of it. (Quoted in Peden 2004: 57)

If we accept this statement at its face value, the Treasury View had a clear foundation in the loanable funds theory, which postulated that total credit supply was limited by the amount of savings made by income recipients, so that one borrower could only increase one's share of credit at the expense of another borrower.

But in the same speech Churchill seemed to downplay the importance of a theoretical argument in the definition of the Treasury View by stating that when appealing to government expenditures

for the purpose of curing unemployment the results have certainly been disappointing. They are, in fact, so meagre as to lend considerable colour to the orthodox Treasury doctrine which has been steadfastly held that, whatever might be the political or social advantages, very little additional employment and no permanent employment can in fact and as a general rule be created by State borrowing and State expenditure. (Ibid.) $)^{8}$

It was the experience with poor results that counted, rather than the theoretical principle enunciated earlier. That was the way supporters of the British Treasury preferred to present it.

Most of the officials that formulated the core of the Treasury View were not professional economists but career civil servants (see Peden 2004; Middleton 1985). Their perspective was mostly shaped by what they believed to be sound principles of public finance rather than of macroeconomics, which in fact was being created as an independent discipline precisely during those years. Perhaps even more important, Treasury officials saw their mission as being to curb unreasonable demands of politicians on the resources of the State. Maintaining balanced budgets was a way to achieve this goal. It imposed the need to find new tax revenues to cover any increase in expenditures (Middleton 1985).

7. One should not assume that it was the position only of the Conservative Party, even though the source here is Winston Churchill, then Chancellor of the Exchequer. It would be more accurate to say that it was the view of the civil service. Labour governments at that time shared the same view. Even some liberal critics, such as Hubert Henderson, Keynes's co-author of Can Lloyd George Do It?, seemed to accept it, at least when facing Keynes's implicit criticisms of the Treasury View in The General Theory of Employment, Interest and Money (1936). Henderson in fact became an implacable critic of The General Theory because of its policy implications.

8. Churchill also offered a more general summary of the Treasury View: 'The classical doctrines of economics have for nearly a century found their citadels in the Treasury and the Bank of England. In their pristine vigour these doctrines comprise among others the following tenets: Free imports, irrespective of what other countries may do and heedless of the consequences to any particular native industry or interest. Ruthless direct taxation for the repayment of debt without regard to the effects of such taxation upon individuals or their enterprise or initiative. Rigorous economy in all forms of expenditure whether social or military. Stern assertion of the rights of the creditor, national or private, and full and effectual discharge of all liabilities. Profound distrust of State-stimulated industry in all its forms, or of State borrowing for the purpose of creating employment. Absolute reliance upon private enterprise, unfettered and unfavoured by the State' (quoted in Clarke 1988: 29). Most, or all, of these points, however, are too general in nature to be useful for the present discussion. 
Therefore, the view emerged less as a semi-formed doctrine than as a body of arguments raised against the expansionary policies proposed mostly during the period between the return to the gold standard in Great Britain in 1925, and when the country abandoned it in 1931.

Great Britain had returned to the gold standard at the same exchange rate of the pound to the US dollar used before World War I. The rate was consensually acknowledged to overvalue the pound. British authorities, however, believed that price flexibility would promote the required nominal adjustments to remove the disequilibrium. While waiting for those adjustments to happen, however (or if they simply did not happen at all), the economy would lose competitiveness and output and employment would fall. As the 1920 s approached their end, pressure mounted on the government to stop relying on automatic adjustments and to implement expansionary policies. ${ }^{9}$

Under the gold standard, monetary policy was constrained to protect gold reserves. Monetary authorities, even if they wanted to, could not use interest-rate policy to stimulate the economy. For many economists, under these conditions, the only policy tool left was to implement a public works program to counteract the deflationary forces of the overvalued currency. It was in this context that the Treasury View emerged and its main focus was defined: opposition to activist fiscal policy. In modern times, it is remembered only as an archaic argument against fiscally induced macroeconomic expansion based on an almost superstitious attachment to Say's law. Surprisingly, perhaps, theoretically based arguments, however, were in fact rarely raised by Treasury officials. There is little reason to suppose that the view's defenders were trying to hide their colors by avoiding the issue. Internal documents of the Treasury published in Peden (2004) show the relatively little weight carried by theoretical arguments even in internal memoranda not intended for publication of any sort. ${ }^{10}$

In any case, if one is concerned with theoretical issues, it was not Say's law per se that inspired the Treasury View, but the loanable funds theory according to which investment activity depended on the supply of credit, which was itself dependent on the savings of the general public. ${ }^{11}$ In this context, public spending, even for investment, was believed to use up resources from the available savings fund, reducing the supply of credit for private investors. Crowding-out could only be avoided if public investments were to be financed by the creation of new money. In this case, however, inflation would ensue because total investment would be greater than savings. Private expenditures would be reduced because of the fall in real purchasing power held by private agents. In other words, public investment would crowd-out private expenditure, with no positive net effect on the overall level of activity and employment in any case. ${ }^{12}$

This is not the place to make a proper critique of the loanable funds theory. But one should keep in mind that the question of how to finance public expenditure while avoiding crowding-out private expenditure was the central point of debate between Keynes and

9. Skepticism about the intrinsic adjustment properties of monetary economies to nominal shocks such as the one represented by the return to gold at an overvalued exchange rate was manifest in Keynes's famous pamphlet The Economic Consequences of Mr Churchill, where he predicted the difficulties the British economy would face if the decision to return to gold under those conditions prevailed. The British experience in the late 1920s described in the pamphlet, included in volume 9 of Keynes's Collected Writings, seemed to have inspired Keynes's arguments against the reliance on automatic adjustment mechanisms in The General Theory.

10. Some officials did believe in Say's law, most notably perhaps Otto Niemeyer, one of the few professional economists in the Treasury's staff. Others were less orthodox, such as Ralph Hawtrey.

11. Churchill's quote, above, authorizes this interpretation.

12. Cf. Middleton (1985: 153), Clarke (1988: 58), and Peden (2004: 80-81, 84). 
the Treasury in the late 1920s and early 1930s. It is only fair to acknowledge that Keynes himself took quite a long time to present a more forcefully consistent argument in this respect. Even then his argument was not really absorbed either by civil servants or, in fact, by academic economists. The apparently interminable debate opposing liquidity preference and loanable fund theories, which still goes on, seems to bear witness to the inability of its participants to settle the question. ${ }^{13}$

Treasury officials often pointed out that positive effects of an increase in public expenditure would be rather limited, in any case, given the degree of openness of the British economy beside the need to finance fiscal deficits. ${ }^{14}$ Leakages would occur through two channels: an increase in incomes, if it could be achieved, would increase imports. Since British exports depended on incomes earned in the rest of the world, deficits in the trade balance would emerge that had to be financed. Financing the deficit could be difficult, however, because newly created financial resources could be used to increase external investment rather than internal expenditure, reducing gold reserves and threatening the value of the pound. This was the second leakage reducing the impact of government spending on domestic output and employment. The problem would be especially serious if an increase in public expenditure reduced confidence by private agents on the wisdom of political leaders, stimulating capital flight.

In fact, the impact of increasing government expenditures and deficits on private confidence was a central concern of Treasury officials and became an essential element of Treasury View (Middleton 1985: 185). Capital flight was not the only channel through which the loss of confidence would express itself. More immediately, interest rates on public securities issued to finance the expenditure would rise, increasing financing costs for private investors as well (quite independently of the more mechanical crowding-out effect mentioned earlier). Maintaining fiscal discipline even in the face of adversity would signal virtuous intentions on the part of the authorities and would contribute to keeping interest rates low and financing conditions adequate for private and public borrowers. Treasury officials believed that the improvement of confidence would be more efficient in promoting recovery than increasing public spending.

But operational concerns also loomed large in the positions assumed by the British Treasury. ${ }^{15}$ Treasury officials insisted that Keynes, perhaps the most active proponent of increasing government expenditures at the time, underestimated the difficulties of using public investment as a demand management instrument by government authorities. Defining and implementing projects took longer than Keynes seemed to acknowledge long enough, in the view of Treasury officials, to make it useless to try to smooth out fluctuations in unemployment (Peden 2004: 103, 106, 107). Officials also called attention to the fact that, in Great Britain, a large share of public investments was made by local

13. To this day this remains a point of contention among Keynesian economists as well as among economic historians. Again, this is not the place to explore this issue, but a possible explanation for the difficulty of understanding Keynes's point was the peculiar sense in which he used the word finance. Middleton (1985), for instance, considers that by the end of his exchange with Bertil Ohlin in The Economic Journal about the determination of the interest rate, Keynes had accepted loanable funds theory. For an examination arriving at the exactly opposite conclusion, see Cardim de Carvalho (2015b: ch. 6 cit.). A discussion starting from different methodological assumptions, arriving at the same conclusion, is Lindner (2015).

14. 'In the considered view of the authorities, Keynes was judged unrealistic on the scope and schedule of public works; over-optimistic on the scale of secondary employment and the likely savings on the dole; and insufficiently mindful of the effect on international confidence of efforts to finance such a programme' (Clarke 1988: 293).

15. Middleton (1985), Clarke (1988), and Peden (2004) all agree on this point. 
administrations. Under these conditions, it could be exceedingly difficult to coordinate an overall expenditure strategy by the central government (Middleton 1985: 18).

Finally, the Treasury View also relied on the notion that most of British unemployment at the time was structural, rather than cyclical. ${ }^{16}$ Moreover, it was distributed throughout the country in very unequal ways. For both reasons, it could not be eliminated or significantly reduced by general measures to increase aggregate demand. ${ }^{17}$ Treasury officials took solace in the thought, often repeated in their memos, that Roosevelt's New Deal had proved that public investment does not offer an efficacious way out of a large crisis. ${ }^{18}$

Arguments of a more political nature were also raised (Middleton 1982). Two points stood out. The first dealt with the question of who should decide which investments governments should make. The argument was raised that it would increase the power of the state over society if government bureaucracies were charged with the authority to choose among investment projects instead of private individuals. Besides, in the case of Great Britain, a centrally coordinated public investment plan would trip over local governments who were legally responsible for a large share of such expenditures.

Treasury officials were deeply concerned with the loss of control over public finances that allowing expenditures to be made without previous provision of funds would entail (ibid.). This is perhaps the most important of all Treasury View features: the notion that the Treasury had conquered the right to manage public finances on behalf of the nation against the anarchy and squandering of resources that previous systems, dominated by undisciplined monarchs and politicians, entailed. Breaching budget discipline created an unacceptable risk: it could become a precedent, rather than an exception. Again, politicians could not be trusted (as kings before them) to contain their impulse to put their hands in the public purse. Balanced budgets, to be executed under tight control by civil servants, were a guarantee that this victory for modernity over aristocratic abuses would be preserved. ${ }^{19}$

16. Middleton (1985) is particularly insistent on the structural and regional character of mass unemployment in Great Britain in the late 1920s and early 1930s.

17. The argument was sort of a cliché among Treasury officials, although the empirical basis for such a claim was not once presented, at least in the documents collected in Peden (2004). One should note, anyway, that in the absence of macroeconomic theories that could explain what all the occurrences of large-scale unemployment had in common it was necessarily the particularities of each situation that would attract attention.

18. Treasury officials, in fact, seemed to be remarkably ignorant of the actual impact of President Roosevelt's policies on the US economy, even though they referred to it frequently. It may be interesting to contrast the diagnosis offered by the British Treasury to the Public Works Administration experience in the first two years of President Roosevelt's first term in office. A large share of public works financed by the federal government was actually decided and realized by local authorities. At least in some areas, the program was considered to be quite successful. See, for example, Williams (2013) for an extensive examination of New Deal building works in New York City, and Smith (2006) for a detailed examination of the public works initiatives of the New Deal.

19. The view that allowing fiscal deficits to emerge once, even if for good reasons, would open the door for fiscal irresponsibility by politicians is an old warhorse of conservative criticism of Keynes's policy proposals. See, for example, Buchanan (1987: 142): 'The Keynesian policy model seemed to offer an intellectual-moral argument for expanded public spending financed by debt (or money). But ordinary politics fails almost totally when the other side of the Keynesian policy norms is required for macroeconomic purpose. Political decision makers cannot increase taxes so as to generate compensatory budgetary surpluses. The bias toward deficits emerges directly from the most elementary application of public choice of principles. In this context, the net contribution of the whole Keynesian half century must be evaluated negatively. It is represented best by the regime 
The 'discovery' of the consumption multiplier by Kahn and Keynes did not change the Treasury View. Uncertain about how to react to the notion, Treasury officials did not consider it acceptable to include estimates of the multiplier effect in their tax projections. The notion could make sense, but working with 'theoretical' estimates could vitiate the whole budgeting process and open the door to the consideration of all kinds of politically motivated views as to the strength of the multiplier (Middleton 1985: 33).

Let us try to summarize the arguments that defined the Treasury View before moving on: (i) the Treasury View was more concerned with proper rules of behavior than with theoretical notions about how modern economies work; (ii) the Treasury View was developed for defensive purposes, to resist proposals to expand public spending during the late 1920s; (iii) to the extent that economic theory was involved in the formulation of the Treasury View, it was the loanable funds theory, according to which the supply of credit is limited by current savings, that played the essential role; (iv) the concern with proper rules of behavior was the main reason why the Treasury View insisted on balanced budgets: it was expected that allowing fiscal deficits to emerge would destroy any inhibition politicians could have of spending without limit the resources of the state; (v) theoretical innovations such as the consumption multiplier were irrelevant for the budgeting process: relying on its predictions would make budgets as reliable as any other theoretical speculation; (vi) public works programs could not work in Great Britain because any worthy investment would require long planning and would infringe on the right of local governments to decide their own priorities; and (vii) to the extent, again, that economic theory had any relevance to the political debate, the Treasury View was characterized by a static view of efficiency, relying on the notion that private agents knew better than the government what was the best use of available resources.

\section{THE BUNDESFINANZMINISTERIUM VIEW}

If in the 1920s and 1930s it was the British Treasury that led the resistance against increased government spending to overcome the depression, in the 2010s the position was clearly taken over by the German Federal Ministry of Finance (BMF) ${ }^{20}$ The 2008

of massive and continuing budgetary deficits that we observe, deficits that bear no relationship to any alleged macroeconomic purpose, and that are almost universally acknowledged to have adverse consequences for the economy as well as for the moral bases of modern society. These deficits emerged because the Keynesian impact was to dislodge almost totally the precept of budget balance from the effective fiscal constitution.' Notice that a similar inflationist bias is frequently denounced as characteristic of Lerner's Functional Finance approach.

20. For economy of space, we will use the acronym BMF in the rest of the paper to refer to the positions defended not only by the German Federal Ministry of Finance, but by the German government as a whole, more clearly since 2010. Other members of the German government also defended the policies described below, even if less frequently or forcefully, including Chancellor Merkel and the Minister of Economic Affairs and Energy, Social Democrat Sigmar Gabriel. The policy was also supported by Bundesbank officials and European Commissioners and officials, and by the German Council of Economic Experts (GCEE). It is noticeable that while the Bundesbank and the GCEE tend to defend more liberal (in the European sense) views as to how a social market economy should work, relying on private markets that are as free as possible, the Ministry of the Economy and Energy, headed by Mr Gabriel, defends redistributive measures as an integral part of the government's overall strategy and the concept of the social market economy itself. But while there are divergences around the degree of social protection that the social market economy should provide to workers and pensioners, no fundamental disagreement seems to exist in regard to the centrality of fiscal consolidation and structural reforms defended by the Federal Ministry of Finance. 
financial crisis, and its belated impact on eurozone countries, catapulted the German government to a position of political protagonism on the international scene that the country had seemed reluctant to accept for most of the post-World War II period.

As already observed, the initial reaction to the financial crash consisted of internationally coordinated expansionary fiscal and monetary policies, agreed in the G20 meeting of heads of government and of state in late 2008. ${ }^{21}$ The policies were successful in putting a floor under the spiraling contraction of economic activity, but at the cost of a significant increase in fiscal deficits and public debt. The fall in output was contained, but a stronger recovery demanded additional fiscal stimulus. Germany, however, spooked by its own fiscal deficit in 2009, began pushing for fiscal consolidation instead of additional stimuli.

When the shock waves generated by the financial crisis hit eurozone countries, they quickly took the form of a 'sovereign' debt crisis. ${ }^{22}$ To control and resolve the crisis, rescue packages were designed by the aforementioned troika of institutions. The eurozone rescue packages were designed to have the packages offered by the IMF to its members since the 1970 s as a template: loans at interest rates lower than those demanded by private investors were made available in exchange for the adoption of a list of conditionalities. These conditionalities included fiscal austerity and structural reforms. ${ }^{23}$

Not surprisingly, the troika faced similar criticisms: that austerity caused the crisis in borrowing countries to deepen and that structural conditionalities were too intrusive. The critics addressed the troika, but most of them always had the German authorities in mind, especially in the Federal Ministry of Finance, who insisted on the need for fiscal consolidation and structural reform as preconditions for recovering sustainable growth in the eurozone (and, in fact, in the rest of the world).

\subsection{Origins: the notion of the social market economy}

Germany's strong attachment to fiscal austerity and pro-competition structural reform should not be surprising. They have both been essential pillars of the social market economy

21. One referee warns me that in fact by this time Germany was still resisting joining the shortlived 'Keynesian' consensus of the G20 and it was only in early 2009 that the country agreed to pursue some fiscal stimulus policies.

22. In a sense, all debt in the eurozone is 'foreign' debt since it is denominated (and redeemable) in a currency that is not under the control of each country's authorities.

23. The IMF used to demand fiscal and monetary austerity from the members benefiting from rescue packages. In the case of the eurozone, monetary policies were decided by the European Central Bank, so that borrowing governments could only take responsibility for fiscal austerity. Structural conditionalities were a later addition to the Fund's conditionalities. They were introduced after the collapse of the Bretton Woods fixed exchange rate system in the early 1970s, when only developing countries still appealed to the IMF to manage balance-of-payments crises. The Fund judged that balance-of-payments crises in developing countries occurred not only because they adopted inadequate macroeconomic policies but also because they were structurally unfit to recover and sustain external stability. As a result, the IMF began to demand structural reforms as conditionalities. Mostly, structural conditionalities referred to institutional reforms to be introduced in labor, product, and financial markets. These markets were believed to be uncompetitive because of excess regulations, the existence of state monopolies, and other barriers to the free adjustment of prices according to supply and demand. Structural reforms generally consisted of liberalization measures in all three markets. Demands for structural reforms reached their zenith in the Asian crises of the late 1990s and the Fund was severely criticized for its excess of zeal. Structural reforms were toned down afterwards but they staged a strong return in the troika's rescue packages for eurozone members. On the performance of the IMF in the Asian crises, see Cardim de Carvalho (2000). 
'model' pursued since the end of World War II, first in West Germany and then in the reunified country after 1990 , with short interruptions.

Beginning in 1947, the occupying forces of the United States and the United Kingdom offered increasing degrees of autonomy to local administration in their respective occupation areas, ultimately leading to the creation of the Federal Republic in 1949. The first West German Chancellor, Konrad Adenauer, nominated Ludwig Erhard as his Economy Minister. Erhard, a man of strong liberal views, adopted the concept of the social market economy, in opposition to a strict laissez-faire view. Erhard's main target at the time, however, was not Keynes or Keynesian policies, but the enthusiasm for planning that he identified in certain circles that leaned in favor of a Soviet-type command economy as was thought to be implemented in East Germany. The social market economy should be a system defined by two main characteristics: (i) market processes are led by private agents operating within a context of anti-monopoly regulation (allowing the state to prevent private exploitation of markets by large firms and conglomerates); and (ii) social security legislation is designed to protect the lowest income classes and the unemployed. ${ }^{24}$

Any idea of state intervention in the operation of the economy, beyond regulation and provision of a social safety net, was strongly rejected. Erhard, however, did not have aggregate demand management in mind and rarely referred to Keynesianism in his public pronouncements. ${ }^{25}$ He seemed to be much more concerned with counteracting the possible attractiveness of command economies, the model being adopted in East Germany, in the eyes of impoverished and demoralized Germans. Moreover, the memory of the interventionist excesses of the Nazi regime, which subordinated economic policy to rearmament goals, besides its politically sinister character, was obviously always an explicit or implicit reference in his speeches. There was little opposition to Keynesianism as such, except to the extent that it was believed to be just a first step on the ladder leading to totalitarian control, either of the Nazi or the Soviet variety. Besides, active state intervention was believed to require closing the economy to some degree, to avoid leaking abroad the expansionary effects of public spending. Open trade and finance, however, were among the most fundamental principles defining the social market economy 'model' proposed by Erhard (again, in contrast with the Nazi regime).

The idea is not far-fetched that the German economy during Erhard's times did not face any significant aggregate demand constraint. The relevant barriers to expansion

24. Despite his frequent references to the expression 'social market economy,' Erhard seemed to have a somewhat fuzzy understanding of the concept. Most of the time it seemed to combine the emphasis on free competitive markets (which should mean not only keeping governments out of markets as much as possible, but also curbing private monopolies) with some measure of social protection to those at the basis of the social hierarchy. At times, Erhard added more characteristics to define the concept, such as admitting some measure of economic planning to reduce uncertainties for the private sector, but the core features seem to be free markets and focused social safety nets. An interesting source of Erhard's ideas is the collection of speeches and press articles, Erhard (1963), which informed this section of the present paper.

25. Erhard (1963) contains only one reference to Keynes: 'The misunderstood Keynes doctrine is just as much out of date now as the early liberal conception which forbade the intervention of the state in things economic' (ibid.: 274). In that text, Erhard did not elaborate on what was the nature of the 'misunderstanding' surrounding Keynes's doctrine but he made clear that Keynesianism was not a real threat: 'The real danger - and I cannot say this too often - comes from the social planners and romantics, who believe that the complex life of a nation can be reduced to a blueprint, who see the intricate process of free co-operation in purely mechanical terms and who start out with romantic ideas of a social system in which man, as God created him, is a mere abstraction' (ibid.). 
were the costs of occupation, the legal and regulatory constraints imposed by the victorious powers, and the lack of access to imported raw materials and essential foodstuffs. The solution to these problems resided in expanding exports and foreign trade. Exports were 'the' source of finance for the import of vital raw materials and foodstuffs without which the country could not survive. Foreign trade was strictly controlled by the Allies in the first years after the war. When the newly constituted West German government was given the power to run its own foreign trade, expansion of exports and imports was pursued with determination. To stress an important point that would shape the country's view of what should be the focus of efficient crisis resolution: foreign trade expansion became part of the foundations of the revived German economy. Exports, however, were not to be understood as an element of aggregate demand, an outlet for domestic production, but as the source of finance that allowed essential imports to be realized. ${ }^{26}$

It was understood that the expansion of German exports had to be based on innovations. A relatively poor country in terms of natural resources (for which it depended on imports), Germany could only become competitive on the basis of constantly introducing innovations to cut labor and other production and operational costs. Increasing productivity was to be the key to the survival of the German Social Market Economy. To innovate was the task of entrepreneurs, businessmen willing to improve their competitive standing by changing production methods or producing new goods and services. ${ }^{27}$ The role of the state was to preserve macroeconomic stability to reduce private uncertainties, to protect the more vulnerable sections of the population through social security, and to curb private excesses, such as the attempts by the largest firms to build monopoly positions. If those functions were adequately performed, no need for Keynesian counter-cyclical policies, with their perverse by-products, would emerge.

A key aspect of the macro-stability that the state should seek to preserve related to the defense of the purchasing power of the Deutsche Mark, created in the monetary reform of 1948 , after the period of monetary chaos that followed the surrender. ${ }^{28}$ The central bank that was created to manage the new currency (which later became the Bundesbank) had the almost exclusive function of keeping the threat (or the ghost) of hyperinflation away. The central bank was to become a stronghold of anti-Keynesian orthodoxy, a stand it has maintained to this day. In fact, the rigidity of the Bundesbank stance constituted the immovable obstacle faced by the short-lived resistible attempt by Minister Karl Schiller to implement Keynesian expansionary policies during the tenure of Chancellor Willy

26. Erhard (2015) describes in detail the role of foreign trade in the rapid economic recovery of West Germany.

27. One prominent German economist, Herbert Giersch, a long-term member and head of the Council of Economic Advisors, identified Joseph Schumpeter as one of the inspirations for the policy strategy. Another former member of the Council, Ernst Helmstädter, also defended the priority given in the policy model to innovation, arguing that a particular kind of Say's law applied to innovations (in these cases, he argued, supply would create its own demand). See Giersch (1993: chs 2 and 8) and Helmstädter (1988: 416).

28. Right after the monetary reform of 1948 , Erhard stated that 'the stability of the new money can never be threatened so long as we settle down to systematic public budgeting and, by means of an equally systematic monetary and credit policy, see to it that our commodity production and our purchasing power remain in harmony' (Erhard 1963: 47). Later, in 1952, Erhard stated that 'the Federal Government is firmly resolved to maintain a balanced budget at all costs. The German people's experience of the tragedy of inflation was such that no one is likely to deviate from the straight and narrow path and risk a recurrence of such a dangerous development' (ibid.: 121-122). 
Brandt. The Bundesbank's refusal to accommodate fiscal deficits amplified the risks of public spending crowding-out private spending. ${ }^{29}$

The notion of the social market economy is assumed to have oriented government policies for most of the period following the end of World War II, since Christian Democrat cabinets ruled Germany, alone or in coalitions led by them, for practically all these decades. Different policies were tried in the short intervals where Social Democrats, always in coalitions, led the government, under Willy Brandt, Helmut Schmidt, and Gerhard Schröder, particularly when the latter's finance minister was Oskar Lafontaine. But even in those exceptional years, financial orthodoxy was strongly defended by the Bundesbank, which used monetary policy to constrain the ability of Social Democrat governments to adopt expansionary fiscal policies.

One would not expect, of course, that the notion of the social market economy, on the other hand, would impose unique choices on the several Christian Democrat governments that were in power after the end of the war. Germany's circumstances during each period, plus the degree of pragmatism with which different leaders would design their actions and strategies, certainly created room for variation within the limits set by the concept of the social market economy itself. To follow the way different governments (and particularly different finance ministers) interpreted and abided by the concept is of great interest, but it is outside the scope of this article.

The three elements just discussed - the emphasis on expanding exports, on the reduction of labor costs through innovation and labor market flexibility, and on monetary stability - seemed to have become ingrained in the long-term German collective memory as requisites for successful policy-making. ${ }^{30}$

\subsection{The BMF View in the 2010s ${ }^{31}$}

There are many important similarities between the British Treasury View of the 1920s and 1930s and the BMF View in the 2010s. There are also, however, many important,

29. The inflexibility of the Bundesbank seemed to have at times exasperated even Ludwig Erhard himself. Cf. Allen (1989).

30. As the Financial Times correspondent in Germany observed in late 2014, 'even on the left of the ruling coalition, there are no demands for domestic growth-boosting policies. Klaus Barthel, the SPD deputy chairman of parliament's economics committee, told the FT: "we are on the right lines" (Wagstyl 2014).

31. The material on which this section is based is different from what we used to characterize the Treasury View. Access to the Ministry of FInance's internal documents is not possible as was the case with the Treasury View. Of course, the difference is a matter of temporal proximity. British Treasury documents for the 1920s and 1930s were released to the public a long time ago. In contrast, when dealing with the Federal Ministry of Finance we are interested in events that are still developing. We should not, therefore, expect the same facility of access to the current financial policies of the German government or of the European Commission as is possible with the Treasury Views of the 1920s. This forces us to give much more weight to the pronouncements of authorities such as Minister Schäuble than we did to the views of, say, Winston Churchill. Like Mr Churchill, $\mathrm{Mr}$ Schäuble is not a professional economist, but this in itself should not pose a particularly serious problem. We are not directly interested, in this paper, in the academic economists' debates on fiscal austerity, as important as they certainly are. One consequence, of course, is that many arguments raised by authorities may rely on theoretically fragile foundations or may be insufficiently developed and thought through. As suggested by one of the referees to this article, perhaps one should not dignify the BMF's view by calling it a 'strategy.' On the other hand, Mr Schäuble has been most insistent and forceful in his defense of fiscal austerity in his frequent speeches, interviews, and 
maybe even essential, differences between them. Because of that, criticisms of the BMF based solely, or even mostly, on arguments developed against the Treasury View may fail to weaken the case for fiscal austerity as currently presented.

Some of the differences between the positions of the British Treasury and the BMF are probably just the result of the dramatic contextual evolution that separates the 1920s and 1930s from the 2010s.

Three important changes distinguish the context in which austerity was proposed by the British Treasury in the 1920s-1930s and by the German Federal Ministry of Finance in the 2010s. First, when British Treasury officials opposed expansionary policies in the 1920 s, they were expressing their skepticism toward largely unsubstantiated claims by economists and publicists regarding the power of fiscal policy to take the economy out of stagnation. There was no evidence that fiscal policy had this power. In particular, there was no actual evidence that a multiplier operated in the economy to increase the impact of government expenditures on national income. ${ }^{32}$ Besides, government spending represented a very small fraction of national income (the amount of which was itself also largely unknown) and it was not easy to figure out how it could be quickly increased to cover large output gaps such as the one opened by the Great Depression. ${ }^{33}$

The German view in the 2010s, in contrast, relies on an assessment of the post-World War II experience with counter-cyclical fiscal policies. The debate has switched to the issue of whether the state had not grown too large since the end of the war. While Treasury officials in Great Britain wondered aloud how and where they could spend money in public works, European Union officials are concerned with ways of reducing public spending at least as a share of GDP. High unemployment, given the limited social safety nets of the 1930 s, gave way to concerns with a possibly over-extended social security protection that, in the view of many in Europe, were reducing incentives to work and burdening society as a whole.

In sum, the Treasury View was developed by state officials working for small governments that had no hard evidence about the power of fiscal spending to lead to income increases. In contrast, the BMF View is proposed for countries where the rule has been Big Government, to use Minsky's expression, and where the burden of a crisis on the weakest strata of society has been attenuated by the existence of extensive social safety nets.

The second difference of context relates to the constraint on fiscal policies posed by monetary factors. Adherence to an international monetary standard is common to both experiences, the British between 1925 and 1931 and Germany in the 2010s. But while Germany and most of the EU countries are tied together by the treaties that created the euro and defined its management, Great Britain in the second half of the 1920s accepted the International Gold Standard. The Gold Standard is a much more fragile arrangement than a common currency area. The Gold Standard is not supported by treaties. One joined it by unilateral initiative and left it in the same way. Of course, countries joining the International Gold Standard did not approach lightly the possibility of leaving it.

press articles, presenting his views on the basis of arguments that clearly suggest familiarity with the relevant economic theory. Moreover, they seem to be politically effective at least with the German public.

32. It is interesting to remember that President Roosevelt himself refused to consider multiplier effects of investments in public works in his budget proposals. This explained his preference for relief initiatives over spending on public works in the first years of the New Deal. See Stein (1990: 57-60) and Smith (2006: 96).

33. Stein (1990: 14) observed that '[i]n 1929 total federal expenditures were about 2.5 per cent of the gross national product, federal purchases of goods and services about 1.3 per cent, and federal construction less than .2 per cent' in the United States. 
To a large extent, adherence to the Gold Standard was sought for its credibility impact, both among its domestic constituencies and among international investors who could give preference to debt securities issued in Gold Standard countries. One knew that a general push for higher prices (and wages) would fatally lead to a liquidity squeeze that would, by increasing interest rates, cause a contraction in the economy. But if the price of adherence became too high, countries could abandon the Gold Standard, as Great Britain in fact did in 1931, and the United States too in 1933, followed by practically every other major country, in a sequence ending with France in 1936.

The euro, by contrast, is a creation of treaties. Countries cannot join or leave it unilaterally. In fact, it is not even clear whether a member country can actually leave it at all. In addition, contrary to the role of gold in the Gold Exchange Standard that was generally practiced in the early twentieth century, the euro is not just a money-ofaccount or a reserve asset against which means of payment can be issued. The euro is, directly, a means of payment, which has replaced national currencies. Liquidity constraints on the member countries are more immediate and stringent. To prevent the kinds of imbalances that in the Gold Standard could force a country out, eurozone member-countries gave up monetary powers and accepted explicit constraints on their domestic fiscal policies. The Maastricht Treaty of 1992 specified limits on fiscal policies, setting ceilings to fiscal deficits and the size of public debt. The Stability and Growth Pact of 1997 strengthened the constraints on national fiscal policies. ${ }^{34}$ When the financial crisis hit the eurozone in 2010, fiscal consolidation conditionalities were added to the rescue packages offered to crisis countries in the zone. But those conditionalities were only effective after eurozone countries got themselves into a crisis and demanded rescue. Additional constraints on domestic policies, of a preventive character, were needed to discipline the remaining members before they actually gotten themselves into trouble. The most important of these so far is the Fiscal Compact, signed in 2012 in the framework of the Treaty of Stability, Coordination and Governance in the Economic and Monetary Union, which establishes tougher rules of control on national fiscal policies (ECB 2012: 101-102).

All this means that while one can say that both Great Britain in the late 1920s and eurozone countries in the 2010 s faced monetary constraints that limited their fiscal space, the ones faced by the latter are much more stringent than those met by the former. When Great Britain unilaterally left the gold standard in 1931, many of the practical objections to expansionary fiscal policies were weakened, if not removed altogether. In the case of the eurozone, no country seemed to have seriously entertained the possibility of leaving the euro or knew how to do it.

Nevertheless, even in the eurozone fiscal space has not been completely eliminated. The European Commission seems of late to have become somewhat more flexible in the judgment of budget proposals by countries like France, Italy, Spain, and Portugal. ${ }^{35}$ Also, which may be more important, it has always been clear that the liquidity constraints imposed by a monetary standard like the euro could be relaxed if the monetary authority were willing to accommodate an expanded level of economic activity in the area as a

34. These limits, however, proved not be as constraining as the writers of the treaty expected, and were violated by no less than Germany and France, the two most important founders of the Union. 35. Ludger Schuknecht, the Chief Economist of the BMF, has recently lamented that in fact ' $[\mathrm{m}]$ ost Western governments stopped pursuing policies of budget consolidation for the time being,' which, he also seemed to lament, 'many leading Keynesian economists think [to be] a good idea' (16 June 2016, URL: http://www.bundesfinanzministerium.de/Content/EN/Standardartikel/ Topics/Public-Finances/Articles/2016-06-16-public-finances-at-a-crossroads.html). 
whole. A country attempting to accelerate its own domestic growth in isolation will quickly meet a barrier in the form of current-account deficits. ${ }^{36}$

This is a similar problem to that explained by Keynes in his Treatise on Money (1930) whereby a banking system as a whole can expand more or less indefinitely but an individual bank cannot grow in isolation for too long because it will lose reserves to the banks that did not expand. Under an international monetary arrangement, if there are no provisions to supply liquidity for individual countries that grow more rapidly than other members of the same arrangement, growth will inevitably stall at some point. On the other hand, if the whole area expands more or less at the same pace, there is no reason for such an imbalance to emerge. ${ }^{37}$

The third context difference between the Treasury and the BMF Views is that the British Treasury was exclusively concerned with the demands for the adoption of expansionary fiscal policies in Great Britain itself, while the BMF is a blueprint not only for German policy-making itself but also for other countries in the European Union. Of course, different countries at any given moment may be going through diverse stages of the business cycle even in a common currency area. Applying similar policy rules to countries in diverse cyclical phases is bound to create severe problems. ${ }^{38}$ Besides, the BMF offers a policy strategy which is also intended to apply to European Union members in general, even the countries that did not join the euro. In fact, as German authorities have made very clear in forums like the G20 or the Bretton Woods institutions' annual general assemblies, the blueprint is supposed to be appropriate even for all the other market economies.

The BMF policy strategy, thus, is not limited to fiscal austerity. It consists of the combination of fiscal consolidation, structural reforms, and incentives to innovative (private) investment. German authorities believe that such a blueprint should be applicable to any market economy. ${ }^{39}$ Greece, Ireland, Portugal, or Spain are all expected to adopt it just as much as Germany has. National differences in cyclical timing, institutions, and governance may explain stronger emphases on this or that set of initiatives, but the blueprint is the same. Besides, all countries face the risks of complacency and moral hazard, although the risk is bigger in some cases than in others. Trailing the virtuous path may be painful so there is always a powerful incentive to drift. ${ }^{40}$ Some countries may just

36. As was exemplified by France during the first three years of Mitterrand's presidency.

37. Monetary accommodation, however, would entail an increase in indebtedness by those countries needing financial cover for current-account deficits. As we will see below, this alternative would violate one of the cardinal principles espoused by the German Federal Ministry of Finance: that increasing debts may be an evil in themselves, quite independently of the reasons why they may be increasing.

38. In one of his most important speeches, Minister Schäuble left no doubts about the need for all eurozone members to share the three-pillar BMF strategy of fiscal consolidation, structural reform, and investment stimulus. See http://www.bundesfinanzministerium.de/Content/EN/Reden/2015/ 2015-04-15-columbia-university.html.

39. Germany performed its own structural reforms with Chancellor Schröder's Agenda 2010, in 2003. A summary of Schröder's reforms is given at http://www.eurofound.europa.eu/observatories/eurwork/articles/chancellor-proposes-agenda-2010-to-revive-economy.

40. In fact, Germany itself seems to fallen prey to moral hazard recently. At least, such is the view expressed by the GCEE in its 2016 report: 'The reform track record of the current government is disappointing. From the point of view of the German Council of Economic Experts (GCEE), the economically successful period - which was partly a result of past reforms - was not used sufficiently to prepare the German economy for future challenges. In view of decreasing innovation and disruptive technological changes, the Federal Government should have aimed much more at strengthening 
be unable by themselves to avoid straying away from consolidation and reform so rescue packages and other devices have to be used to keep them in line. ${ }^{41}$

The emphasis on moral hazard is much stronger in the BMF View than it was in the Treasury View, maybe because the latter was supposed to be concerned only with Great Britain. The British Treasury was of course concerned with the possibility that agreeing to run fiscal deficits could lead politicians to take advantage of the popularity of government spending without fearing the risk of upsetting taxpayers who would have to pay more taxes if the fiscal budget was to remain balanced. But the BMF, in its turn, is concerned not only with Germany, where this risk could be lower, but also with 'Southern' European countries where moral hazard could be an even bigger problem. Countries like Greece, Italy, and even France cannot be trusted to implement painful measures except under external pressure. The BMF, it seems, could agree in theory that some policy programs could be too tough, but relief in this case would fatally reduce the incentive for the concerned country to mend its ways. ${ }^{42}$

Many of the contrasts between the views of the British Treasury and the BMF seem to result from the fact that the Treasury View was defensive in nature, aiming at deflecting demands for fiscal activism to preserve the efficient operation of private markets, while the BMF position is offensive, aiming at reforming existing economic structures and promoting growth. The Treasury View focused on the static efficiency of markets, while the BMF is concerned with increasing long-term growth rates. Without exaggerating the

market forces and promoting structural change through suitable reforms' (GCEE 2016: 7). The Council is especially critical of the raise in minimum wages and pensions decided by the Merkel government.

41. Minister Schäuble has been very insistent on the importance of considering moral hazard in the policy-making process. Pressures should be maintained on crisis countries, because relief would break their will to promote reforms. In a speech to the Bundestag, Schäuble stated that: 'But, ladies and gentlemen, there is something we need to understand, because it's true: People I mean people like us, societies, especially in democracies - do not like to make changes when things are going well; we only accept changes when we have to, when there is no other way, when there is a crisis. That is something I've had occasion to realise in the past. In that respect, perhaps it is not an easy time for far-reaching reforms, because we are still so well off. But we mustn't accept that as the final word' (cf. http://www.bundesfinanzministerium.de/Content/EN/Reden/2016/2016-09-26Accept-challenges-maintain-stability-security.html). The manifest opposition of the German authorities to the creation of European bonds is inspired by the same concern with moral hazard: 'Any mutualisation of liability would actually weaken competitiveness - whether we're talking about eurobonds or collective liability for banks' legacy assets. It would create the wrong incentives and give the impression that state support is guaranteed in every case' (cf. http://www.bundesfinanzministerium. de/Content/EN/Reden/2014/2014-03-27-bruges.html). Pointing to moral hazard has been a central point of BMF rhetoric, and is repeated continuously by Minister Schäuble and other authorities. On at least one occasion, the Minister in fact attributed the global crisis to moral hazard: 'A lot of people underestimate the problem of moral hazard. But if you separate decision-making power from accountability, and if you separate opportunity from risk, you cannot succeed. That was the main cause of the financial crisis' (cf. http://www.bundesfinanzministerium.de/Content/EN/ Reden/2015/2015-04-17-brookings-washington.html).

42. In other words, the toughness of rescue conditionalities in the case of eurozone members may be inspired, at least in part, by the objective of maintaining pressures on borrowing countries to reform their structures and balance their budgets as quickly as possible rather than by actual adjustment requirements. As Minister Schäuble wrote in a 2011 op-ed article for the Financial Times, '[t] he recipe is as simple as it is hard to implement in practice: western democracies and other countries faced with high levels of debt and deficits need to cut expenditures, increase revenues and remove the structural hindrances in their economies, however politically painful' (Schäuble 2011). 
importance of such a distinction, it is clear that BMF aims at increasing investment, while for the Treasury View how society spends its income is a private problem.

But the BMF is not concerned with maximizing the volume of investment alone. The insistence on the importance of innovative investments betrays some influence of Schumpeter, although one can argue that this influence is stronger in the case of the Ministry of the Economy and Energy. ${ }^{43}$ In Minister Schäuble's case such an influence is never acknowledged but his concern with innovations and competitiveness is permanent:

We need a forward-looking recovery. Conventional government programmes are not the answer. What we need are the right conditions that will generate innovations to strengthen our competitiveness. We need to invest in research and innovation to create the jobs we need. ${ }^{44}$

The emphasis on growth and innovation leads the BMF into areas that did not seem to worry the British Treasury. While for the British Treasury maintaining fiscal balance was an end in itself, for the BMF fiscal consolidation should not be considered in isolation to structural reforms to increase productivity, reduce labor costs, and increase productivity which would result in improved competitiveness for local producers. Fiscal consolidation would reduce the dead weight of the state, while structural reforms would actually promote innovation and growth. In Mr Schäuble's own words:

But what is even more important is that structural reforms must be aimed at improving the economic conditions, including, most importantly, making an economy more innovative. That's why we have structural reforms. ... Ultimately, structural reforms to promote the capacity for innovation mean improving the framework conditions for the financing of business ideas especially high-risk business ideas. We are doing that now with the capital markets union and with the promotion of capital-market-based corporate financing in general. ${ }^{45}$

The BMF is also concerned with the increase in debt, public and private, to a much greater degree than the British Treasury was. The latter was concerned with crowdingout, a result of its acceptance of loanable funds theory. The problem, for the British Treasury, was that public investment would absorb credit (and savings) that would otherwise be directed at supporting private investments. The BMF blames directly credit creation and debt growth for the financial crisis fed by the counter-cyclical monetary and fiscal policies

43. Cf. MEE (2015). The report, in fact, goes beyond the reference to the importance of innovations as the main competitive weapon in modern market economies, to express priorities that seem taken directly from Schumpeter's (1980) Theory of Economic Development. For instance, MEE officials expect that start-ups will be the main promoters of innovation. There is a concern with the financing of start-ups that reflect directly Schumpeter's thinking of the entrepreneurial function as independent from the functions of both capitalists and managers of existing concerns.

44. Cf. http://www.bundesfinanzministerium.de/Content/EN/Reden/2014/2014-03-27-bruges. $\mathrm{html}$. The point is repeated in many other speeches and press articles. Even Chancellor Merkel, after stating how much bigger Europe's contribution to world output is than its population share, and how large is the area's contribution to world social spending, concludes ' $\mathrm{t}$ ] hat shows the magnitude of the challenge facing us. That is why innovation capacity and competitiveness are key issues for Europe' (cf. https://www.bundesregierung.de/Content/EN/Reden/2014/201402-19-oecd-merkel-paris_en.html).

45. Cf. http://www.bundesfinanzministerium.de/Content/EN/Reden/2015/2015-03-26-structuralreforms.html. The minister added at the end of the speech: 'To cut a long story short: There is no trade-off between fiscal consolidation and structural reforms, particularly labour market and welfare reforms. On the contrary, they typically complement each other.'. 
that followed after the end of World War II. Ultimately, it was the dominance of Keynesian views among policy-makers that was responsible for such imbalances:

For more than two decades, economic policy in industrialized countries has tried to avoid recessions sacrificing fiscal prudence and monetary rectitude in the process. When financial markets crashed, central banks, particularly in Anglo-Saxon countries, cut interest rates. ... One result of such misguided policies was a series of debt-financed asset bubbles.... When the last of those debt-financed bubbles burst three years ago, governments had to up the ante and use massive fiscal stimuli and central banks had to resort to unprecedented measures of easing monetary policy to avoid the breakdown of financial markets and an ensuing depression. To be fair, those measures have been necessary to avoid a depression. But Keynesian deficit spending has had unfortunate consequences: Governments' debts and deficits are on the verge of spiralling out of control. At least markets think so, withdrawing their confidence and demanding higher risk premiums, i.e. interest rates. ${ }^{46}$

But the elements shared by the Treasury and BMF Views are also important. Both rely on the notion that private economic decisions are, as a rule, more efficient than decisions made by the state. The British Treasury, as observed, argued that private markets allocate resources more efficiently. The BMF argues that private markets innovate, and therefore support progress, more consistently than is the case with investments by the state.

Another point of strong convergence is the fear that fiscal deficits and increasing public debt can erode the confidence of consumers and investors. The Treasury View tended to be more specific than the BMF View: falling confidence would reflect itself on rising interest rates paid on public debt, in the context of the gold standard. The BMF, on the other hand, generally mentions unspecified confidence effects, negative in the case of persistent fiscal deficits and rising public debt, positive otherwise. The failure to identify explicitly the ways in which variations in confidence would affect consumers' and investors' behavior (and why) does not prevent the BMF from making strong predictions as to the importance of this variable:

There is some concern that fiscal consolidation, a smaller public sector and more flexible labour markets could undermine demand in these countries in the short term. I am not convinced that this is a foregone conclusion, but even if it were, there is a trade-off between short-term pain and long-term gain. An increase in consumer and investor confidence and a shortening of unemployment lines will in the medium term cancel out any short-term dip in consumption. (Schäuble 2011)

Finally, a distrust of parliamentary politics similar to the one expressed by British Treasury officials (Middleton 1982) seems also implicit in BMF views that national governments have to be prodded to take decisions they would not take without external pressure. Fiscal austerity, the idea that public spending can only be increased in parallel with the provision of the tax revenues necessary to cover them, should keep in check the attempts of

46. Cf. http://www.bundesfinanzministerium.de/Content/EN/Reden/2011/2011-09-27-berlin. $\mathrm{html}$. The same theme, with some variations, was repeated on other occasions. See, for example, http://www.bundesfinanzministerium.de/Content/EN/Reden/2010/2010-06-24-handelsblatt.html; http://www.bundesfinanzministerium.de/Content/EN/Reden/2011/2011-09-27-berlin.html; http:// www.bundesfinanzministerium.de/Content/EN/Reden/2015/2015-03-27-bundesbank.html; and http://www.bundesfinanzministerium.de/Content/EN/Reden/2015/2015-04-17-brookings-washington.html. Blaming Keynesian anti-cyclical policies for the crisis was not consensual, however. Commissioner Olli Rehn, for one, seemed to disagree, pointing out that, with the possible exception of Greece, fiscal weakness was the result, not the cause of the crisis in the eurozone. Cf. Rehn's speech of 5 May 2012, URL: http://ec.europa.eu/economy_finance/articles/governance/2012-05-05-oli-rehn_en.htm. 
politicians to provide free lunches to their constituencies. There is a widespread perception that the German experience with the disorganization of the Weimar Republic, followed by Nazism and the collapse of East Germany in the early 1990s would have worked as a vaccine against taking liberties with fiscal budgets. The BMF seems to acknowledge that Keynesianism is not, of course, a totalitarian ideology, but its complacency with fiscal discipline could be the prologue to some more destructive regime.

A conspicuous absence from the BMF is any concern with effective demand. ${ }^{47}$ All emphasis is put on competitiveness, which means that one can always sell more if one can beat his or her competitors, independently of the size of total demand. Of course, competitiveness is a relative concept and there cannot be an increase in competitiveness benefiting all producers. In macroeconomic terms, it can only make sense if one is thinking of expanding net exports, that is, exporting more to other countries than it imports from them. Germany seems to follow this policy without any guilt and oblivious to the fact that it merely exports unemployment to other countries instead of eliminating it. To rely on the expansion of net exports means that somebody will have to accept deficits in the current account. It may be a solution for individual countries, but it does not represent much progress in comparison to the beggar-thy-neighbor policies of the 1930s. On the other hand, increasing competitiveness under a common currency can only result from two sources: (i) increasing productivity, through technical progress, which, of course, is not a variable entirely or even approximately under the control of government authorities; and (ii) internal devaluation, that is, the reduction of production costs, particularly labor costs, with respect to competitors, which means reducing wages as far as needed to make domestically produced goods cheaper than those produced by competitors.

In conclusion, we can summarize the BMF View with the following propositions: (i) it is developed in a context of a common currency managed by an independent multinational central bank, under tighter requirements than those imposed on Gold Standard countries; (ii) it is formulated for conditions where the state is already big and an active participant in the economy, as a regulator, a buyer, and provider of goods and services, and, in some cases, as a producer; (iii) the 'new times' are also defined by the presence of extensive social safety nets that attenuate the burdens of unemployment; (iv) it aims at promoting innovative private investments that can increase competitiveness and, although it is rarely made explicit, can find new markets by dislocating higher-cost competitors; (v) public budgets should be kept balanced, yearly if possible, but certainly in cyclically adjusted terms, allowing for the action of endogenous stabilizers when needed; (vi) debt, public or private, has to be contained to avoid amplifying cyclical fluctuations (but there are specific limits only to public debt which has to be contained below the ceiling of 60 percent of GDP according to the Maastricht Treaty); (vii) psychology is an

47. As reported by The New York Times in 2014, one of the three main arguments made by Berlin was that ' $[\mathrm{t}]$ he eurozone's economic problem is largely one of supply rather than of demand' (Taylor 2014). In the same spirit, Minister Schäuble stated that 'the problem [of unemployment] resides more with finding qualified workers and with bottlenecks in the planning procedures at the regional and communal levels' (cf. http://www.bundesfinanzministerium.de/Content/EN/Reden/2016/ 2016-06-10-swiss-austrian-conference.html). The notion that the way out of the crisis was to be found through supply rather than demand policies was shared in other quarters. In 2013, in an interview for Le Monde, Philippe Aghion, an advisor to François Hollande at the time, stated that it is necessary to replace the welfare state by the strategist state that invests in human capital, innovation and the strengthening of professional careers. A state that manages the cycle through supply rather than through demand, helping businesses and individuals to maintain the innovative character of their investments in times of recession: instead of Keynesian, it is necessary to become Schumpeterian' (Kahn/Escande 2013). 
important consideration in policy-making, particularly through confidence effects and moral hazard that can nullify the effects of expansionary fiscal policies; and (viii) democratic systems per se create a fragile barrier against attempts by diverse groups to profit from the ability of the state to distribute favors so that building institutions able to constrain such forms of behavior is essential. One final essential argument of the BMF is that if austerity is required when a country faces balance-of-payments constraints and when exchange-rate devaluations are excluded by multinational monetary arrangements (such as the euro), internal devaluation is the only way out of a crisis. Fiscal austerity becomes, in this case, not only an instrument to reach fiscal balance but also for inducing the reduction of domestic labor costs that can increase the affected country's external competitiveness.

\section{EVALUATION}

Both the Treasury and the BMF Views approach balancing budgets as a value for political rather than purely economic reasons, in contrast with Keynesianism for which the fiscal budget is just a policy tool. In Great Britain balanced budgets were the symbol of the modernization of the state achieved in the nineteenth century. ${ }^{48}$ Allowing fiscal deficits or, worse, actively seeking fiscal deficits would open the door for the irresponsibility of politicians to roll back all the reforms that guaranteed that the state would maintain sound public finance. In Germany, if anything, the memory was even more dramatic, of the chaos of the Weimar Republic or of Nazis discretionarily intervening in the economy to promote rearmament and warfare. Eliminating the power to effect discretionary spending is seen as key to safeguarding rule-based modern societies if not modern civilization itself.

Such views seem to find an echo in the general population (or among voters). The public appears to instinctively fear fiscal deficits and the growth of public debt on the false belief (shared by political leaders) that a country works just like a big family, of which the government is the head. The head of a family is supposed to know that he or she cannot permanently spend more than he or she earns because doing it will lead to bankruptcy. Many believe the situation may actually be worse in the case of fiscal deficits and public debt, given the ease with which it is possible to get into debt until it is too late to avoid bankruptcy.

The idea that governments are subject to the same financial constraints as a family is a fallacy of composition that Keynes and Keynesians have been obviously unsuccessful so far in dispelling. ${ }^{49}$ The focus of the debate should not be fiscal deficits but government spending. Deficits (or surpluses) are results, not instruments. As Keynes himself noted, ideally governments would signal through their spending policies that they are prepared to support full employment and this should be enough to stimulate private spending and for income and tax revenues to rise, possibly arriving even at a balanced budget at the end. ${ }^{50}$

48. 'Treasury officials' criticism of Keynes were often motivated by determination to defend a system of what they conceived to be sound public finance. They had inherited a tradition, going back to Sir Robert Peel and William Gladstone, whereby, at least in theory, the state should be politically neutral as between different economic interests, and should interfere with market forces as little as possible' (Peden 2004: 3).

49. The fallacy is to miss the fact that while a family's expenditures are unlikely to affect their own income, the opposite happens with government expenditures. By spending, the government is able to increase aggregate income and, thus, tax revenues.

50. See Kregel (1983) and Cardim de Carvalho (1997). 
Another common view shared by voters, political leaders, and some economists, is that to promote recovery through aggregate demand management is to believe that it is possible to create something out of nothing, an act of magic rather than of government. ${ }^{51}$ Nevertheless, the notion that in the presence of idle capacity and unemployed workers the goal must be to increase aggregate demand should not be particularly difficult to understand or to accept. ${ }^{52}$ It is appealing to intuit the proposition that one has to save before one can invest (how could one invest something that has not yet been created?). The complexity of Keynes's alternative argument apparently has prevented the clarification of the issue in the political debate.

While the Treasury View was clearly directed against counter-cyclical fiscal policies, the BMF's target is not so clear. Frequently, the BMF's arguments are presented to oppose the notion that government spending can lead and sustain long-term development. Although it is certainly true that there are a few critics of austerity who rely on a stagnationist view of modern capitalist economies (that some prefer to call mature), this by no means represents the mainstream of austerity critics. On the contrary, the point raised by supporters of expansionary policies is that this is the way not only to support private investment but also to generate the confidence entrepreneurs need in order to jump into the turbulent waters of innovative investment. ${ }^{53}$ But, as we saw in the preceding section, sometimes the BMF fires its guns against counter-cyclical fiscal and monetary policies as well.

A point shared by both the British Treasury and the BMF is that it is never explained where the demand will come from for the goods produced by the private firms, either the innovative ones or the others. The Treasury seemed content to rely on Say's law. Once wages were down and lenders' confidence restored, firms would be able to produce more, and in the process create the purchasing power required to absorb that additional production. If prices and wages were flexible enough, the adjustment process would proceed more quickly.

In the case of the BMF, it seems to be implicit in the policy strategy to rely on exports as the outlet for increased production. It is by raising net exports that German authorities hope to recover the economies of the European Union. The argument involves, of course, another obvious fallacy of composition: the notion that increasing net exports can be a general solution for the current crisis. The BMF's arithmetic is rather obviously faulty at this point.

The BMF View is presented by its proponents as a supply strategy, in contrast to the demand strategy of Keynesians. Its core supply strategy for recovery is not really balancing budgets (other than its alleged effect on lenders' confidence and interest rates) but stimulating private investment. The BMF contrasts this goal with what it assumes to be a

51. Franklin Roosevelt, when running for the presidency in 1932, actually said this much, when he discarded appealing to public spending to fight the Depression: 'It is the habit of the unthinking to turn in times like this to the illusions of economic magic,' quoted in Stein (1990: 50).

52. DeLong/Summers's (2012) detailed argument should be persuasive enough. But, as noted, the point is not whether BMF supporters understand the argument. The point is whether they think it relevant.

53. One is not denying the importance of confidence. Nevertheless, recognizing the relevance of confidence does not take us very far in the understanding of how can it be obtained. The now apparently closed debate around the possibility of 'expansionary fiscal consolidations' relied on the idea that budget discipline would increase private agents' confidence and thus their willingness to increase consumption, investment, etc. Guajardo et al. (2011) showed that it did not work that way. Fiscal consolidation has been contractionary, as expected by Keynesians. Even one of the original proponents of the notion of expansionary fiscal consolidation has already acknowledged that the hypothesis was falsified in all the experiments under which it was tested (Perotti 2011; 2014). 
Keynesian goal of using government expenditure to stimulate consumption. It is really unclear where such a characterization of Keynesian policies originates. Most Keynesians, as in fact did both Keynes and Kalecki themselves, actually defend raising public investments, coupled with measures that could stimulate private investment, to jump-start the economy. ${ }^{54}$ The point of contention is not whether private investments should be stimulated but how they should be stimulated: Keynesians believe that nothing is more stimulating than the perspective of growing demand for the goods that will be produced by new plant and equipment, while the BMF seems to think that giving tax favors would be more efficacious (besides, of course, the expected confidence effect, allegedly to be created by virtuous and prudent governments).

The BMF is less insistent on the question of how to finance public expenditure than the Treasury View, perhaps because it already starts from an outright rejection of attempts to revive economies in crisis through government spending. In the same vein, both the $\mathrm{BMF}$ and the Treasury views take as a given that we are dealing with open economies. However, while the latter treated the balance of payments as a constraint on policy choices, the former sees foreign trade as the key to the success of the strategy. Expanding the economy through rising exports not only solves the problem of where the demand for the national output coming from but it also removes the possibility that growth can be constrained by the need to increase imports. For both, by contrast, Keynesianism can only be applied to closed economies, being therefore hopelessly inadequate for advanced economies.

\section{DOES IT WORK?}

At the end of the day, the essential test for any policy strategy must be whether or not it works. But answering questions like this is easier said than done. The meaning of success itself, as well as the time frame in which success is to be evaluated, are subject to debate.

Austerity is a policy recipe to fight crises. Did it lead to actual recoveries? Austerity policies have been imposed on the so-called peripheral countries of the eurozone since 2010 as conditionalities attached to the rescue packages sponsored by the troika. Their performances have been similar: drastic public expenditure cuts and rising taxes lead to a sharp fall in the level of activity and a strong increase in unemployment. Once a country reaches rock bottom, a measure of stabilization, where the downward spiral is contained and some weak and volatile expansion ensues, may be observed. Starting from very low levels of activity, 'recovery' is not enough, however, to return to past peaks of production, let alone past growth trends. The risk of a double dip is always present. Notwithstanding that, political leaders committed to austerity tend to present the recovery as proof of its efficacy. The question remains, of course, how far the previous collapse itself was caused by austerity policies. The fragility of recovery in the recent eurozone countries' experience has been associated with the dependence austerity creates on external demand. On the other hand, growth of net exports has also been dependent on the fall of imports which accompanies the contraction of the economy. It may not be sustained if the economies someday truly recover. This has affected not only peripheral economies, but also at least some of the core economies of the eurozone.

The claim that austerity may stimulate innovation and productivity increases is much harder to evaluate. Proponents of the BMF View are vague about the actual connections between them. Austerity seems to be an important element in a context that favors

54. See, for instance, Keynes (1982: 148, 151, and 158) and Kalecki (1971: chs 2 and 3). 
innovation, although it is not entirely clear why. Some seem to believe that austerity is associated with the notion of responsible government, one that does not threaten private activity and respect its limits. Some others may believe that an austere government is unlikely to raise taxes in the future, threatening to confiscate private profits. BMF proponents mostly emphasize the negative aspect: Keynesianism is supposed to favor consumption, not investment, closed, not open, economies, government intervention and bureaucratic control, not entrepreneurial initiative, and therefore creates an anti-business climate that does not support productive investment. It is a cultural, rather than strictly economic, question.

To some extent, success evaluation of long-term changes of the kind proposed by the BMF runs the risk of becoming circular: fiscal consolidation and structural reforms should promote sustainable growth. If sustainable growth has not been reached it is either because policies fell short of what was necessary or because not enough time has passed for those policies to come to fruition.

Nor should one ignore that austerity has in many cases become an alibi for conservative governments to roll back some of the redistributive reforms implemented since World War II, generally referred to as the 'welfare state.' In the BMF's rhetoric, the mention is frequent of moral hazards created by labor-market regulation and social security systems that reduce workers' willingness to get the jobs that are offered to them. In the eurozone, rescue packages imposed by the troika regularly rely on the assumption that austerity cannot be softened under the pain of reducing the stimulus to reform. In the United States and the United Kingdom, the political right states clearly its goal to reduce the size of the state as a political, rather than economic, objective. ${ }^{55}$

Boyer (1985: 78) wisely noted, when debating similar issues to those treated in this paper, that 'the revival of pre-Keynesian concepts is not simply a matter of propaganda or ideology. However debatable are the policies of monetarist, supply-side, or rationalexpectations schools, they do point to the presence of real macroeconomic problems.' The difficulties faced by Keynesians to sell their alternative policies to voters and political leaders cannot be entirely due to the difficulty to understand the complexities of modern capitalism and the role of the state. There are at least two real problems to be faced by any Keynesian alternative, especially in peripheral countries, both related to the balance of payments.

The first has to do with net exports. A recovery led by domestic demand - say, public investment - in an open economy will face the problem of paying for increasing imports. There will be no reason for exports to grow pari passu with imports, which increase as national income is raised. President Mitterrand tried to make the French economy grow out of a recession in the first year of his first term by stimulating domestic demand, and the policy had to be abandoned because of balance-of-payments constraints. ${ }^{56}$

55. As stated by a conservative newspaperman: 'In the end, you are either a big-state person, or a small-state person, and what big-state people have about austerity is that its primary purpose is to shrink the size of government spending. ... The bottom line is that you can only really make serious inroads into the size of the state during an economic crisis. This may be pro-cyclical, but there is never any appetite for it in good times; it can only be done in the bad' (quoted in Eichengreen 2015: 366).

56. 'It is now clear what are the advantages of an upswing stimulated by means of securing a surplus in foreign trade. It is worth mentioning that the "natural" upswing based on the automatic increase in investment activity does not enjoy these advantages, and if there is no influx of foreign capital, it will be confronted with the same balance of payments difficulties as the upswing based on “domestic exports" [by which Kalecki meant government expenditures]' (Kalecki 1971: 25). 
The second problem is related to the first. Under the euro arrangements, it is even more difficult for individual countries to promote recovery by stimulating domestic demand. The common currency imposes a hard liquidity constraint not only on external deficits but also on domestic fiscal deficits. When fiscal and balance-of-payments deficits and public debt are already large, the perception that a country really has no alternative to bankruptcy other than to submit to austerity becomes overwhelming.

\section{CONCLUSION}

The German government insistence on the adoption of radical austerity policies by crisis countries in the eurozone has been the target of hard and equally persistent criticism at least since 2010. The Germans, however, are undaunted and in fact are bent on trying to convince the international community to follow such a path, as their interventions at the G7 and G20 meetings bear witness. Of course, policy discussions cannot be settled on theoretical issues alone, but one should notice that criticisms leveled at austerity policies defended by the German Federal Ministry of Finance as if they were simple revivals of the old British Treasury View will probably not be effective. The BMF View is, if anything, more complex than the Treasury View ever was. It cannot be faulted for believing in old-fashioned ideas such as Say's law. ${ }^{57}$ But while the Treasury View combatted the idea that expansionary fiscal policies could restore full employment during a crisis, the BMF vows to oppose the notion that fiscal policies could replace private investment as the engine of growth in the long term, which is not what most critics of austerity mean in their criticisms anyway. The weakest spot of the BMF seems to be precisely the core of the austerity strategy: the notion that austerity favors innovation and that recoveries are a result of supply incentives not demand management. No causal mechanism is actually proposed one way or the other. In fact, no argument is provided about how those phenomena are connected and why an increase in aggregate demand caused by an increase in, say, public investments in infrastructure would cause any discouragement to private investors, including Schumpeterian entrepreneurs.

\section{REFERENCES}

Allen, C. (1989): The underdevelopment of Keynesianism in the Federal Republic of Germany, in: Hall, P. (ed.), The Political Power of Economic Ideas: Keynesianism Across Nations, Princeton, NJ: Princeton University Press, 263-289.

Blyth, M. (2015): Austerity: The History of a Dangerous Idea, Oxford: Oxford University Press.

Blyth, M. (2016): Policies to overcome stagnation: the crisis, and the possible futures, of all things euro, in: European Journal of Economics and Economic Policies: Intervention, 13(2), 215-228.

Boyer, R. (1985): The influence of Keynes on French economic policy: past and present, in: Wattel, H. (ed.), The Policy Consequences of John Maynard Keynes, Armonk, NY: M.E. Sharpe, 77-115.

Buchanan, J. (1987): Keynesian follies, in: Reese, D. (ed.), The Legacy of Keynes, San Francisco: Harper and Row, 130-145.

Cardim de Carvalho, F. (1997): Economic policies for monetary economies: Keynes's economic policy proposals for an unemployment-free economy, in: Brazilian Journal of Political Economy, 17(4), 31-51.

57. Helmstädter (1988) suggested that theoretical understanding of Say's law could be very limited in some circles, but he was a member of the GCEE, not of the BMF. 
Cardim de Carvalho, F. (2000): The IMF as crisis manager: an assessment of the strategy in Asia and of its criticisms, in: Journal of Post Keynesian Economics, 23(2), 235-266.

Cardim de Carvalho, F. (2015a): Can Basel III work when Basel II didn't?, in: Papadimitriou, D. (ed.), Contributions to Economic Theory, Policy, Development, and Finance: Essays in Honor of Jan Kregel, London: Palgrave, 347-367.

Cardim de Carvalho, F. (2015b): Liquidity Preference and Monetary Economies, London and New York: Routledge.

Clarke, P. (1988): The Keynesian Revolution in the Making 1924-1936, Oxford: Clarendon Press.

DeLong, J.B., Summers, L. (2012): Fiscal policy in a depressed economy, in: Brookings Papers on Economic Activity, Spring.

Eichengreen, B. (2015): Hall of Mirrors: The Great Depression, the Great Recession, and the Uses and Misuses of History, New York: Oxford University Press.

Erhard, L. (1963): The Economics of Success, Princeton, NJ: Princeton University Press.

Erhard, L. (2015): Germany's Comeback in the World Market: The German 'Miracle' Explained by the Bonn Minister for Economics, London: Routledge.

ECB (European Central Bank) (2012): Main elements of the fiscal compact, in: Economic Bulletin (formerly Monthly Bulletin), March, URL: https://www.ecb.europa.eu/pub/pdf/mobu/ mb201203en.pdf.

GCEE (German Council of Economic Experts) (2016): Annual Report 2016/17, URL: https://www. sachverstaendigenrat-wirtschaft.de/jahresgutachten-2016-2017.html?\&L=1.

Giersch, H. (1993): Openness for Prosperity: Essays in World Economics, Cambridge, MA: MIT Press.

Guajardo, J., Leigh, D., Pescatori, A. (2011): Expansionary austerity: new international evidence, IMF Working Paper WP/11/158.

Hall, P. (1989): The Political Power of Economic Ideas: Keynesianism Across Nations, Princeton, NJ: Princeton University Press.

Helmstädter, E. (1988): The irrelevance of Keynes to German economic policy and to international economic co-operation in the 1980s, in: Eltis, W.A., Sinclair, P.J.N. (eds), Keynes and Economic Policy: The Relevance of The General Theory after Fifty Years, London: Macmillan, 411-427.

Kahn, A., Escande, P. (2013): Ni austérité ni keynésianisme!, in: Le Monde, 14 June.

Kalecki, M. (1971): Selected Essays on the Dynamics of the Capitalist Economy, Cambridge, UK: Cambridge University Press.

Keynes, J.M. (1930): A Treatise on Money, London: Macmillan.

Keynes, J.M. (1936): The General Theory of Employment, Interest and Money, London: Macmillan.

Keynes, J.M. (1982): Activities, 1931-1939: World Crises and Policies in Britain and America, in: Moggridge, D. (ed.), The Collected Writings of John Maynard Keynes, vol. 21, London: Macmillan.

Keynes, J.M. (2013): Essays in Persuasion, in: Moggridge, D. (ed.), The Collected Writings of John Maynard Keynes, vol. 9, Cambridge, UK: Cambridge University Press for The Royal Economic Society.

Kregel, J. (1983): Finanziamento in Disavanzo, Politica Economica e Preferenza per la Liquidità, in: Vicarelli, F. (ed.), Attualità di Keynes, Roma-Bari: Laterza.

Lindner, F. (2015): Does saving increase the supply of credit? A critique of loanable funds theory, in: World Economic Review, 4, 1-26, URL: http://wer.worldeconomicsassociation.org/files/ WEA-WER-4-Lindner.pdf.

MEE (Federal Ministry for Economic Affairs and Energy) (2015): 2015 Annual Economic Report: Investing in Germany's and Europe's Future, Berlin: BWMi.

Middleton, R. (1982): The treasury in the 1930s: political and administrative constraints to acceptance of the 'new economics,' in: Oxford Economic Papers, New Series, 34(1), 48-77.

Middleton, R. (1985): Towards the Managed Economy: Keynes, the Treasury and the Fiscal Policy Debate of the 1930s, London: Routledge.

Peden, G.C. (ed.) (2004): Keynes and his Critics: Treasury Responses to the Keynesian Revolution 19251946, Oxford: Oxford University Press for The British Academy.

Perotti, R. (2011): The 'austerity myth': gain without pain?, BIS Working Paper No 362, November. 
Perotti, R. (2014): Fiscal policies in recessions, in: Akerlof, G., Blanchard, O., Romer D., Stiglitz, J. (eds): What Have We Learned? Macroeconomic Policy After the Crisis, Cambridge, MA: MIT Press, 193-208.

Schäuble, W. (2011): Why austerity is only cure for the Eurozone, in: Financial Times, 5 September. Schumpeter, J.A. (1980): Theory of Economic Development, London: Routledge.

Smith, J. (2006): Building New Deal Liberalism: The Political Economy of Public Works, 1933-1956, Cambridge, UK: Cambridge University Press.

Stein, H. (1990): The Fiscal Revolution in America, revised edn, Washington, DC: The AEI Press. Taylor, P. (2014): Germany keeps its economic engine idling, in: The New York Times, 29 September.

Truger, A. (2013): Austerity in the euro area: the sad state of economic policy in Germany and the EU, in: European Journal of Economics and Economic Policies: Intervention, 10(2), 158-174.

Wagstyl, S. (2014): Berlin holds firm on fiscal rigour despite recession risks, in: Financial Times, 7 October.

Williams, M. (2013): City of Ambition: FDR, La Guardia, and the Making of Modern New York, New York: W.W. Norton. 